\title{
Retracing Realistic Disaster Scenarios from Archival Sources: A Key Tool for Disaster Risk Reduction
}

\author{
Bashir Ahmad ${ }^{1} \cdot$ Akhtar Alam $^{2} \cdot$ M. Sultan Bhat ${ }^{3} \cdot$ Khurshid Ahmad Bhat $^{4}$ •

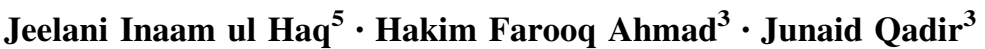

Accepted: 14 March 2021/Published online: 25 June 2021

(C) The Author(s) 2021

\begin{abstract}
Disaster scenarios are constructed by integrating natural hazard phenomena and social science sources of information. We profiled 51 natural hazard events of nineteenth century Kashmir that provide insights into the impacts of varying degree of severity that spread through the socioeconomic and political systems, influenced adaptation, and increased the consequences of the resulting disasters. The root cause of these disasters was embedded in the social, natural, and political economic systems of their time, where vulnerabilities overlapped and interacted periodically with successive colonial regimes and acted as tipping points. The combined effect of successive colonial regimes, inept administration, rigid political economy, and natural hazards made the situation go from bad to worse and reduced Kashmir to the depths of distress and subjugation. Over the arc of the nineteenth century, a series of disasters led the Kashmiri population to learn how to live with disasters and minimize risk, bringing about the evolution of social and environmental knowledge. Understanding the natural hazard vulnerability of the Kashmir Valley through archival narratives can help in scenario
\end{abstract}

Bashir Ahmad

bashirahmad1@live.com

1 Department of Geology, Nawakadal School, Srinagar 190002, India

2 Institute for Risk and Disaster Reduction, University College London, London WC1E 6BT, UK

3 Department of Geography and Regional Development, University of Kashmir, Srinagar 190006, India

4 Department of Statistics, Chanapora School, Srinagar 190015, India

5 Department of Geology, Aligarh Muslim University, Aligarh 202002, India building to translate findings into formats that reduce related risk now as it did then. The resulting information can be useful for regional design, planning, and policy responses to promote disaster risk reduction.

Keywords Disaster risk reduction - Historical disasters $\cdot$ Kashmir $\cdot$ Nineteenth-century disasters $\cdot$ Socioeconomic vulnerability

\section{Introduction}

Reconstruction of disaster scenarios through historical discourse can help to shed light on the circumstances in which a specific hazard event occurs and to determine the extent of the affected population's vulnerability. In pursuit of disaster knowledge, it is imperative to understand how patterns of vulnerabilities interact with severe natural hazards to produce disasters over time, which requires taking an historical perspective into account (GraciaAcosta 2002). This approach allows for the reconstruction of relationships between pre-event vulnerability patterns and the societal impact of natural hazards and disasters, or "societal relationships with nature" (Jahn and Wehling 1998 , p. 75). It is essentially synonymous with the "forensic disasters investigation," which aims to identify root causes and risk drivers (Burton 2010, p. 36; IRDR 2015 , p. 8); or "science of past disaster," as anticipated by Riede (2014, p. 335); and "charting a historical trajectory of disasters," as aptly put by Bankoff (2007, p. 109). Such historical research on disasters can function through "natural experiments of history" (Diamond and Robinson 2010 , p. 1), using disasters as "social laboratories" (Grayson and Sheets 1979, p. 623) to reveal facets 
underlying certain moments or periods (Oliver-Smith 1999; Gracia-Acosta 2002).

Consequently, historical disaster research can make significant contributions to mitigation, management, and reconstruction efforts and to the prevention of disasters among at-risk populations (Oliver-Smith and Hoffman 2002; Schenk 2014; Riede 2017). In disaster management processes, human archives can help to recognize geographic regions as well as societies and individuals (Leroy 2011). These reference collections can help to elucidate how political and socioeconomic realms interact over time with natural environments and vice versa. From the historical perspective, Kashmir was not invulnerable to disasters. Instead the region was intermittently subjected to the impacts of natural hazards with an emphasis towards modern history knowing that this era is rich in archival sources (Kelman et al. 2018). As a result, a case study on the recent past underscores the need to know how the contours of vulnerability adversely impacted Kashmiri population during the nineteenth century and accentuates the continuing need for historical research, not only by calling attention to the on-going role of the past in the present (Palerm 1980), but also by stressing its utility in disaster preparedness efforts (Riede 2014, 2017).

Efforts were made to collect, arrange, and assemble information from the written sources in a chronological order of sequence on physical, biological, social, and political aspects of nineteenth century Kashmir, leading to disasters. Information collated should thus enable us to frame policies and practices that reduce the impacts when events of analogous nature occur. Importantly, post-disaster information will facilitate the effectiveness of hazard and risk assessment and can make options available for governments and civil societies to compromise on specific disaster related issues.

\section{Study Area}

The Kashmir Valley is a nearly completely enclosed terrestrial basin (Fig. 1), with a NW-SE orientation, bounded by the Pir Panjal and Zanskar mountain ranges in the southsouthwest and north-northeast, respectively. The valley is secluded from the rest of western Himalaya by a ring of lofty ranges, unbroken except by a narrow gorge of the river Jhelum flowing southwestward. Kashmir Valley has a large, alluvial fan system that develops from the pediment of the Pir Panjal mountain to the north that conceals most of the subterranean geological structures while the southern side of this orogeny is deformed in thrust (Panjal and Muree thrust) and fold system. Presently, Karewa deposits are topped with loess paleosols. Karstification, mass wasting, and neotectonics are the dominant active processes shaping the geomorphology of the basin. The floodplain of the valley near Srinagar has an average elevation of $1550 \mathrm{~m}$ above mean sea level. Across this floodplain flows the axial river Jhelum, which emanates from Verinag Spring in the south and flows northwest, over nearly the full stretch of the valley. These geomorphic features make the Kashmir Valley genial for human habitation; however, often these factors make it equally vulnerable to various geological and geophysical hazards. Climatic and geomorphic conditions allowed peasantry to recognize four classes of soils: abi (irrigated), sambher (sailabi), nambal (swampy), and khushki (dry) (Wingate 1888). Linked with climate, Rabi and Kharif crops were cultivated by peasantry (Drew 1875), using primitive agricultural implements like light wooden plough with an iron-tipped ploughshare (Wingate 1888). Similarly, pestle and mortar were generally used for husking rice and pounding maize (Lawrence 1895).

\section{Data Sources}

The surviving historical records of Kashmir seldom deal with what can be termed "disaster studies." Rather, information about natural hazards, inclement weather disturbances, and widespread famines, diseases, migration, and deaths appear in a vast array of publications, mostly in one of the two categories. First, local descriptive Persian manuscripts, for example, Majmu'-ut-Tawarikh written by Pandit Birbal Kachru, traces Kashmir history from the earliest times down to 1836 . The chronicler appears to have mainly relied on the Sanskrit and Persian sources like Rajtarangani written by Pandit Kalhana in 1148, Tarikh-iKashmir by Malik Haider Chaudora in 1620, and Wakiat-iKashmir by Mohammad Azam Dedamari in 1747. The manuscript contains adequate information on the history of Mughal and Afghan rule in Kashmir. Besides geography, climate, fauna and flora, trade, and culture, the author records the agrarian relations that existed during the period under review. Next in line is Tarikh-i-Kashmir by Khalil Merjanpuri who touches the history of Kashmir form the earliest times down to the reign of Maharaja Ghulab Singh (1846-1857). Tarikh-i-Kashmir is based on the accounts of Ajiz Narayan Koul (1710), Muhammad Azam Dedamari (1747), and Pandit Birbal Kachru (1836). This account is followed by Wajeez-ul-Tawarikh written by Ghulam Nabi Khanyari and covers the period from the origin of Kashmir up to 1893. It is a short political history with a brief account of the Muslim saints of Kashmir. It also sheds light on the natural calamities that struck the valley from time to time. The most comprehensive of all the Persian sources is Tarikh-i-Hassan written by Pir Ghulam Hassan Khoihami (1885), compiled in three volumes. Its first volume deals 
Fig. 1 Seismotectonic setting of the Kashmir Himalaya. Red dots are instrumental earthquakes from 1960-2016 and yellow dots denote historical events with epicenter in the Kashmir Valley during the nineteenth century

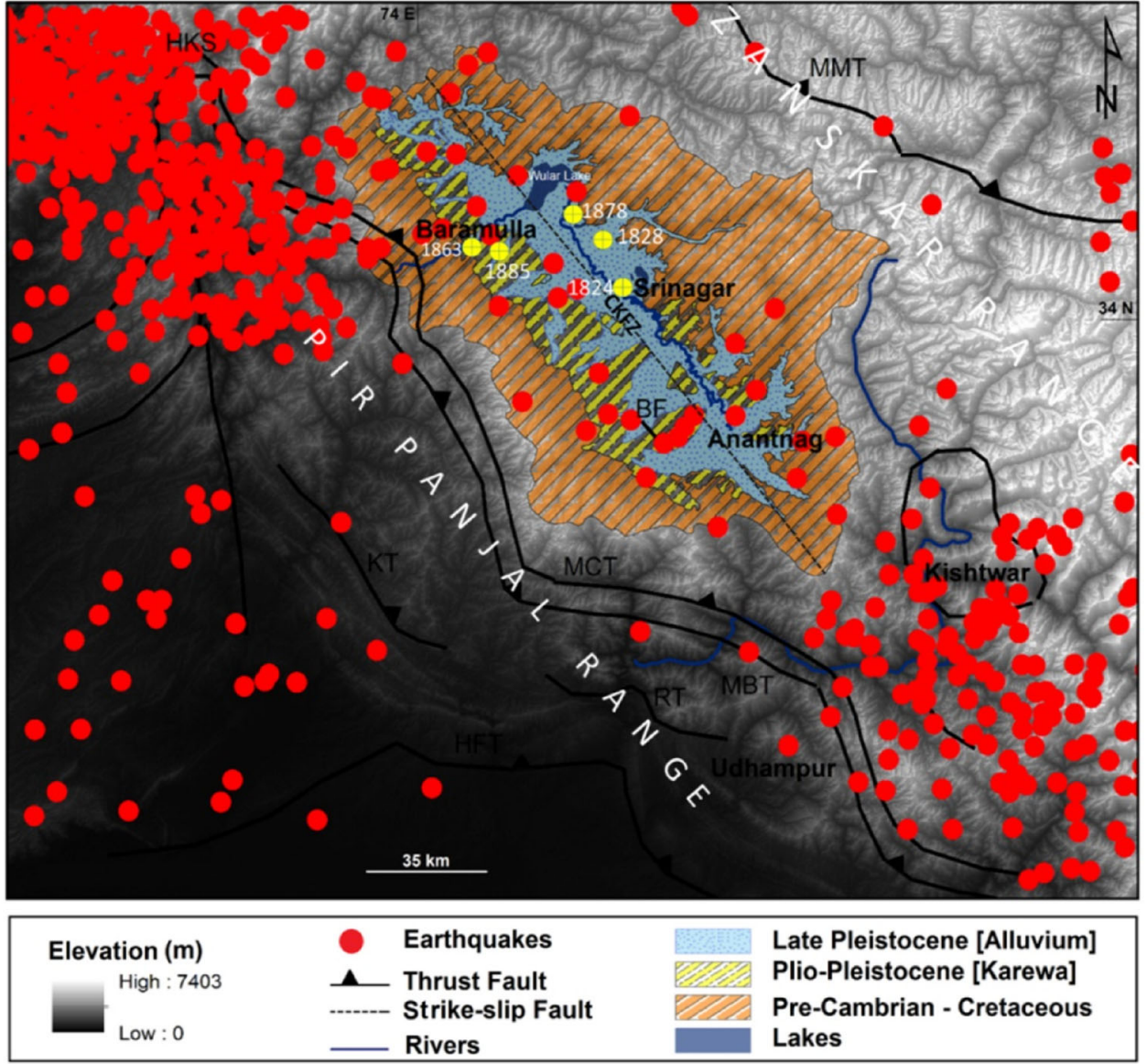

with geography of Kashmir, its fauna and flora, archaeological remains, trade, sources of irrigation and agricultural produce, and so on. The second volume describes the history of Kashmir from the earliest times to the author's own days. The third volume contains the biographies of saints.

The native historians of nineteenth century Kashmir seem to have followed their predecessors who adopted the principles of general historiography and compiled epoch specific evidence in a narrative style. In endeavoring this objective, the modern historians generally divided their accounts into bounded periods that reflect the change in the seat of power among the rulers. These manuscripts are a compendium of details pertaining to sociopolitical, economic, and religious characteristics of Kashmir. Some entries in these manuscripts are spurious and need to be looked at prudently; we undertook vigilant description analysis and comparison to check their genuineness. The running texts of these archival records include natural hazards and their socioeconomic impacts with a distinct historiography covering different time periods of the nineteenth century.

The second category of publications is travelogues penned by many European travellers, for example, Forster
(1808), Moorcroft and Trebeck(1841, pp. 279-281),Hügel (1836),Vigne (1842, p. 480), Schonberg (1853, p. 370), Bates (1873, pp. 110-113),Bellew (1875, p. 454), Drew (1875, p. 627), and Wakefield (1879, p. 356), who recorded natural events and their causes, impacts, and societal responses in Kashmir during the nineteenth century. Later, a British revenue officer named Walter Lawrence (1895) gives an intense description of Kashmir's natural hazards in a masterpiece, The Valley of Kashmir. Over the following 4 decades, the Neve brothers (Neve, A. 1885, 1913a, 1913b; Neve, E.F. 1900, 1915, 1928), who worked as health evangelists in undivided India including Kashmir, provide descriptions related to various facets of Kashmiri society and the state's geography in several travel-accounts.

In addition to the above sources, documents of public authority have survived in large numbers and wide variety-for example, preliminary land settlement reports of Kashmir based on the land ownership, political economy, agrarian reforms, and so on. Similarly, another type of records is the administrative reports often serial in character, for example, administrative reports of late nineteenth century originate from central authority at Lahore, Pakistan during the Dogra rule. The content of these reports is based 
Fig. 2 Natural hazard events in the Kashmir Valley, 1800-1900. Source Wingate (1888), Lawrence (1895) and Bates (1873)

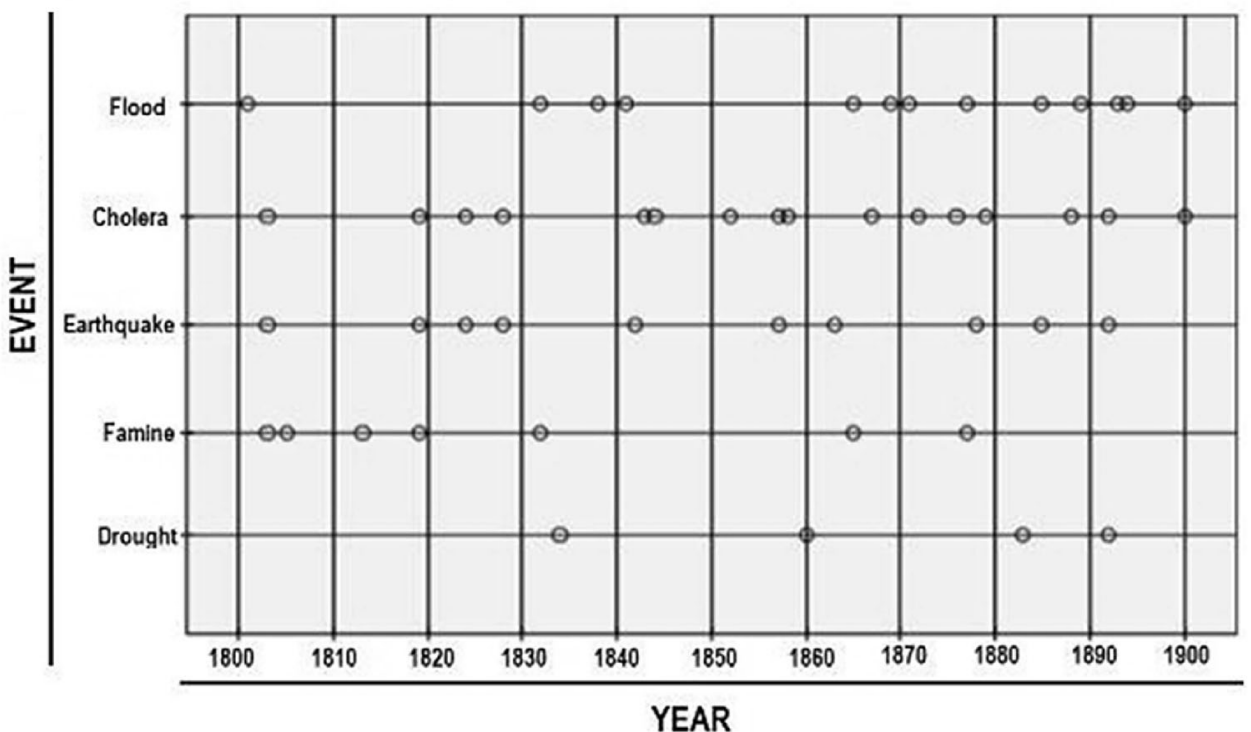

on the income and expenditure incurred on jails, public works, and taxes imposed on public and other affairs of the state.

\section{Disasters: Variability and Complexity}

A meticulous review of archival records enabled us to rediscover a spectrum of hazards (Fig. 2) and to focus on the descriptions of those hazard events around the time they occurred, including their long-term impact on the population during the nineteenth century. The period under review experienced repeated natural hazard events and significant sociopolitical upheavals, sometimes occurring concurrently. In our analysis, basic trends in documented events concerning 51 natural hazards were derived from 36 reliable entries (Table 1). Some of these entries in the table concern more than one phenomenon occurring concurrently. One example is the entry for the year 1803, which reports on a famine and cholera outbreak followed by an earthquake with epicenter at Garwhal Himachal Pradesh felt as far as Kashmir. Similarly, 1819 saw an earthquake and cholera followed by famine, while both 1824 and 1828 witnessed an earthquake and a subsequent outbreak of cholera. Overall, this study reviews the following severe events that struck the Kashmir Valley between 1800 and 1900: 16 cholera epidemics; 13 floods; 10 earthquakes; 7 famines; and 5 droughts. Thus a total of 51 extreme disaster events were considered in our centurylong study of which $31 \%$ were epidemics, $25 \%$ floods, $20 \%$ earthquakes, $14 \%$ famines, and $10 \%$ droughts. Nineteenthcentury Kashmir experienced on average one disaster every 2 years.

\section{Socioeconomic and Political Vulnerability}

After Afghans invaded Kashmir in 1752, replacing the Mughal rule, the nineteenth century witnessed transformative political events that resulted in the colonial occupation of Kashmir. Sikhs ejected the Afghans at the end of second decade of the nineteenth century (1819) and later, during the mid-nineteenth century (1846), Dogras ${ }^{1}$ dethroned the Sikh administration, with general plunder and looting at each power shift (Lawrence 1895). In the interludes between successive colonial regimes, socioeconomic and political ecological conditions set the stage for natural events to turn into disasters. That led Forster (1808) to equate the relations of the ruler and his subjects with that of the master and his servants. Moorcroft and Trebeck (1841, vol. 2, pp. 124-125), Hügel (1845, p. 464), Vigne (1842), Ince (1888), and Lawrence (1895) subscribed to the same opinion. Under colonial conditions, peasants did not have the right to sell or mortgage the land they occupied (Neve 1913a); failure to pay government dues rendered them expelled (Collette 1884). The village upper class comprised Hindu landowners (India 1890), with the majority Muslim peasantry serving the former's interests (Bazaz 1941). Moreover, land revenue was paid in kind, which corresponded to one-sixth of the produce during Mughal rule (Lawrence 1895). Later, in areas under Afghan rule, tax demand on land was increased to one-half of the produce (Khoihami 1885; Hassan 1959).

\footnotetext{
${ }^{1}$ Dogras were the last colonial rulers of Jammu \& Kashmir, and annexed the independent state of Jammu \& Kashmir in 1846. Gulab Singh was the first Dogra Dynasty ruler of Jammu \& Kashmir, and his family ruled until 1947 when British rule of India ended and India became an independent country.
} 
Table 1 Hazard events, their societal impacts, and population estimates in the Kashmir Valley, 1800-1900

\begin{tabular}{|c|c|c|c|}
\hline Year & Events & Description & Sources \\
\hline 1801 & Severe flood & Severe flood followed by famine & Kachru (1836) and Miskeen (1899) \\
\hline 1803 & $\begin{array}{l}\text { Famine, } \\
\text { cholera, } \\
\text { earthquake }\end{array}$ & $\begin{array}{l}\text { An earthquake causes severe ground shaking and crustal } \\
\text { deformation in the villages and Srinagar City, with loss of } \\
\text { life and property. The epicenter of this earthquake was at } \\
\text { Garwhal Himachal Pradesh }\end{array}$ & Khanyari (1893), Khoihami (1885) and Miskeen (1899) \\
\hline 1805 & Famine & Excessive cold results in crop failure followed by famine & Kachru (1836) \\
\hline 1813 & Famine & Excessive cold results in crop failure followed by famine & $\begin{array}{l}\text { Kachru (1836), Miskeen (1899), Khoihami (1885) and } \\
\text { Wingate (1888) }\end{array}$ \\
\hline 1815 & $\begin{array}{r}\text { Population } \\
\text { estimate }\end{array}$ & 800,000 persons & Wingate (1888) \\
\hline 1819 & $\begin{array}{l}\text { Earthquake, } \\
\text { cholera, } \\
\text { famine }\end{array}$ & $\begin{array}{l}\text { Earthquake kills } 1200 \text { persons. The epicenter of this } \\
\text { earthquake was at Allahbund. Later, cholera breaks out and } \\
\text { many Kashmiris flee the country. Famine aggravates the } \\
\text { situation; people sell their sons and daughters }\end{array}$ & Kachru (1836), Purdon (1861) and Miskeen (1899) \\
\hline 1824 & $\begin{array}{l}\text { Earthquake, } \\
\text { cholera }\end{array}$ & $\begin{array}{l}\text { A great earthquake razes every structure in Srinagar City. In } \\
\text { the following couple of months, all inhabitants live in tents. } \\
\text { Epicenter of this seismic event was at Srinagar. This was } \\
\text { followed by cholera then breaks out }\end{array}$ & $\begin{array}{l}\text { Bates (1873, pp. 110-113), Wakefield (1879), Wingate } \\
\text { (1888) and Ram (1895, pp. 132-133) }\end{array}$ \\
\hline 1828 & $\begin{array}{l}\text { Earthquake, } \\
\text { cholera }\end{array}$ & $\begin{array}{l}\text { An earthquake kills } 1000 \text { persons and destroys } 1200 \text { homes, } \\
\text { including many great houses. Crustal deformation occurred } \\
\text { at several places in Kashmir. Epicenter of this earthquake } \\
\text { was at Srinagar. Devastation of 14-pier bridge at } \\
\text { Doderhama Ganderbal. A majority of the people are } \\
\text { rendered homeless, naked, hungry, weak, and neglected. } \\
\text { The corpses of the dead litter the area, and cholera breaks } \\
\text { out, which claims many more lives. A census of the dead is } \\
\text { started, but withdrawn as it becomes unmanageable to } \\
\text { continue the census }\end{array}$ & $\begin{array}{l}\text { Vigne (1842, p. 283), Khanyari (1893), Miskeen (1899) } \\
\text { and Khoihami (1885) }\end{array}$ \\
\hline 1832 & $\begin{array}{l}\text { Famine, } \\
\text { flood }\end{array}$ & $\begin{array}{l}\text { After heavy autumn rains destroy rice crops in } 1831 \text {, heavy } \\
\text { snowfall and severe cold freeze all rivers and lakes in } 1832 \text {, } \\
\text { leading to a severe famine, followed by a crippling } \\
\text { economic crisis. The situation compels many hungry } \\
\text { people to march down to Lahore, Delhi, Calcutta, Banaras, } \\
\text { and Amritsar. Famine kills three-fourths of the population }\end{array}$ & Kachru (1836), Suri (1849) and Lawrence (1895, p. 530) \\
\hline 1834 & Drought & $\begin{array}{l}\text { A scarcity of rainfall produces drought, causing about } 70 \% \text { of } \\
\text { the population to live in a state of near-starvation }\end{array}$ & $\begin{array}{l}\text { Wakefield }(1879, \text { p. } 356), \text { Lawrence }(1895, \text { p. } 530) \\
\text { Shoemaker }(1912, \text { pp. 283-425) and Paremu (1977, } \\
\text { pp. 47-49) }\end{array}$ \\
\hline 1835 & $\begin{array}{r}\text { Population } \\
\text { estimate }\end{array}$ & 200,000 persons & Lawrence (1895, p. 530) and Bates (1873, pp. 110-113) \\
\hline 1838 & Great flood & $\begin{array}{l}\text { A great flood occurs, forcing inhabitants to take to their boats. } \\
\text { The flood is described as one to which there was no } \\
\text { existing record in the living memory }\end{array}$ & $\begin{array}{l}\text { Bates (1873, pp. 110-113), Digby (1890, pp. 176-180) } \\
\text { and Koul (1925, pp. 98-112) }\end{array}$ \\
\hline 1841 & Severe flood & $\begin{array}{l}\text { A severe flood causes damage to life and properties, including } \\
\text { six bridges that were swept away from Srinagar. Khanyar, } \\
\text { Rainawari, Kawdarah including Chattabal were submerged }\end{array}$ & $\begin{array}{l}\text { Bates (1873, pp. 110-113), Khasta (1888, pp. 169-170), } \\
\text { Digby (1890, pp. 176-180) and Koul }(1925, \\
\text { pp. } 98-112)\end{array}$ \\
\hline 1842 & $\begin{array}{l}\text { Heavy } \\
\text { snowfall, } \\
\text { earthquake }\end{array}$ & $\begin{array}{l}\text { Heavy snowfall is followed by an earthquake. The epicenter } \\
\text { of this earthquake was at Jalalabad, Afghanistan and the } \\
\text { shocks were felt across Kashmir Valley }\end{array}$ & Paremu (1977, pp. 47-49) \\
\hline 1843 & $\begin{array}{l}\text { Cholera } \\
\text { epidemic }\end{array}$ & $\begin{array}{l}\text { Continuous rains are followed by cholera, which kills } 23,000 \\
\text { people }\end{array}$ & $\begin{array}{l}\text { Digby (1890, pp. 176-180) and Paremu(1977, } \\
\text { pp. 47-49) }\end{array}$ \\
\hline 1844 & $\begin{array}{l}\text { Cholera } \\
\text { epidemic }\end{array}$ & Continuous rains are followed by cholera & Ram (1895, pp. 132-133) \\
\hline 1852 & $\begin{array}{l}\text { Cholera } \\
\text { epidemic }\end{array}$ & Continuous rains are followed by cholera & Ram (1895, pp. 132-133) \\
\hline 1857 & $\begin{array}{l}\text { Cholera, } \\
\text { earthquake }\end{array}$ & $\begin{array}{l}\text { Cholera strikes the valley even though it is winter and the } \\
\text { snowfall measures up to one's neck' Maharaja Gulab } \\
\text { Singh's day of death is marked by an earthquake }\end{array}$ & $\begin{array}{l}\text { Bates (1873, pp. 110-113), Digby (1890, pp. 176-180) } \\
\text { and Lawrence }(1895, \text { p. 530) }\end{array}$ \\
\hline
\end{tabular}


Table 1 continued

\begin{tabular}{|c|c|c|c|}
\hline Year & Events & Description & Sources \\
\hline 1858 & $\begin{array}{l}\text { Cholera } \\
\text { epidemic }\end{array}$ & Many people die of cholera & $\operatorname{Ram}(1895$, pp. 132-133) \\
\hline 1860 & Drought & Water shortages lead to scarcity & Digby (1890, pp. 176-180) \\
\hline 1863 & $\begin{array}{l}\text { Severe } \\
\quad \text { earthquake }\end{array}$ & $\begin{array}{l}\text { An earthquake followed by aftershocks that last for three } \\
\text { months. Epicenter of this earthquake was at Kruhan } \\
\text { Baramulla }\end{array}$ & Miskeen (1899) and Khoihami (1885) \\
\hline 1865 & $\begin{array}{l}\text { Flood, } \\
\text { famine }\end{array}$ & In August two such floods occurred in each of the years & Ince (1888, p. 24) and Khasta (1888, pp. 266-278) \\
\hline 1867 & $\begin{array}{l}\text { Cholera } \\
\text { epidemic }\end{array}$ & $\begin{array}{l}\text { Epidemic cholera raged in Kashmir, there are no statistical } \\
\text { details of the ravages. But the epidemic was a destructive } \\
\text { one }\end{array}$ & $\operatorname{Ram}(1895$, p. 51) \\
\hline 1869 & Flood & Continuous rains are followed by flooding & Digby (1890, pp. 176-180) and Bellew (1875, p. 454) \\
\hline 1871 & Flood & $\begin{array}{l}\text { The whole country becomes flooded and resembles an } \\
\text { extensive lake }\end{array}$ & Ince (1888, p. 24) and Digby (1890, pp. 176-180) \\
\hline 1872 & $\begin{array}{l}\text { Cholera } \\
\text { epidemic }\end{array}$ & Cholera spread due to incessant rains and bad sanitation & Ram (1895, pp. 132-133) \\
\hline 1873 & $\begin{array}{l}\text { Population } \\
\text { estimate }\end{array}$ & 491,846 persons & Ram (1891) \\
\hline $\begin{array}{c}1875 / \\
76\end{array}$ & $\begin{array}{l}\text { Cholera } \\
\text { epidemic }\end{array}$ & $\begin{array}{l}\text { The intermittent appearance of disease from December } 1875 \\
\text { to October } 1876 \text { claims } 1,276 \text { lives. Poor harvest }\end{array}$ & Ram (1895, pp. 132-133) \\
\hline 1878 & $\begin{array}{l}\text { Flood, } \\
\text { famine, } \\
\text { earthquake }\end{array}$ & $\begin{array}{l}\text { Heavy rains and floods are followed by a severe famine. } \\
\text { People die for want of food; men leave behind wives and } \\
\text { children to die. Many orphaned girls are sold by nomads to } \\
\text { rich people in city. Three-fifth of the entire valley } \\
\text { population die }\end{array}$ & Khoihami (1885) and Lawrence (1895, p. 530) \\
\hline 1878 & $\begin{array}{r}\text { Population } \\
\text { estimate }\end{array}$ & 402,700 persons & $\begin{array}{l}\text { Digby (1890, pp. 176-180), Ram (1895, pp. 132-133), } \\
\text { Lawrence (1895, p. 530), Koul (1925, pp. } 98-112) \\
\text { and Rai (2004, p. 335) }\end{array}$ \\
\hline 1879 & $\begin{array}{l}\text { Population } \\
\text { estimate }\end{array}$ & 245,923 & Administrative Report (1880) \\
\hline 1879 & $\begin{array}{l}\text { Cholera } \\
\text { epidemic }\end{array}$ & Famine is followed by cholera & Ram (1895, pp. 132-133) \\
\hline 1880 & $\begin{array}{l}\text { Cholera } \\
\text { epidemic }\end{array}$ & Cholera kills 10,000 people & Mitra (1889, p. 9) \\
\hline 1883 & Drought & For want of rain there appears drought & Rai (2004, p. 335) \\
\hline 1885 & $\begin{array}{l}\text { Earthquake, } \\
\text { flood }\end{array}$ & $\begin{array}{l}3900 \text { human deaths in Kashmir plus } 20,000 \text { horses and } 10,000 \\
\text { cows and oxen. The earthquake induced landslides } \\
\text { concurrently, which caused flooding in the river Jhelum } \\
\text { floodplain }\end{array}$ & Neve (1885) and Khoihami (1885) \\
\hline 1888 & $\begin{array}{l}\text { Cholera } \\
\text { epidemic }\end{array}$ & A cholera epidemic kills 10,000 people & Neve (1900) \\
\hline 1889 & Flood & $\begin{array}{l}\text { The only available detail regarding this flood is that the flood } \\
\text { of } 1889 \text { eroded the house of Mr. Bijex, the then appointed } \\
\text { state engineer }\end{array}$ & Jammu and Kashmir Political (1889) \\
\hline 1891 & $\begin{array}{l}\text { Population } \\
\text { estimate }\end{array}$ & 949,041 persons & Ram (1891) and Collette (1884, pp. 68-69) \\
\hline 1892 & $\begin{array}{l}\text { Cholera, } \\
\text { drought, } \\
\text { earthquake }\end{array}$ & $\begin{array}{l}\text { The chief medical officer states that } 11,712 \text { persons have died } \\
\text { and that an earthquake has devastated the women's hospital } \\
\text { at Rinawari, Srinagar. The epicenter of the earthquake was } \\
\text { at Chaman, Afghanistan }\end{array}$ & $\begin{array}{l}\text { Climo (1893), Carus-Wilson (1901) and Ram (1895, } \\
\text { pp. 132-133) }\end{array}$ \\
\hline 1893 & Severe flood & $\begin{array}{l}\text { The Jhelum floods after } 52 \text { hours of continuous rains, } \\
\text { wrecking } 2225 \text { houses. The flooding is followed by } \\
\text { cholera, which kills } 1000 \text { people }\end{array}$ & Lawrence (1895, p. 530) and Ram (1928) \\
\hline
\end{tabular}


Table 1 continued

\begin{tabular}{llll}
\hline Year & Events & Description & Sources \\
\hline 1894 & Severe flood & $\begin{array}{l}\text { The month of June witnesses incessant and untimely rains } \\
\text { followed by floods; the river Jhelum raises to a level of } \\
\text { about } 3 \text { feet above the mark recorded in the previous } \\
\text { season }\end{array}$ & Administrative Report (1896) \\
1900 & $\begin{array}{l}\text { Continuous rains cause cholera and 4225 people die } \\
\text { severe } \\
\text { flood }\end{array}$ & Ram (1928) & \\
\hline
\end{tabular}

During Sikh rule, the government taxed people at exorbitant rates, sometimes as high as nine-tenths of the whole harvest (Wingate 1888). With the advent of the Dogra dynasty's rule, Ghulab Singh inflated the taxation system from the pre-Dogra era to such a degree that his greed and hoarding acquired infamous magnitudes (Rai 2004). The revenue system was such that whether the peasant worked a lot or a little, they were left with barely enough to get along on until the next harvest (Thorp 1870). This oppressive policy resulted in negligence of land cultivation and vagrancy (Lawrence 1895). In addition to socioeconomic exploitation, the most unusual feature of colonial Kashmir was the corvee or obligatory labor, known as begar in the local parlance, which continued until the middle of the twentieth century. The state had every right to call upon the villagers to perform the duty of begar (Lawrence 1895). During the nineteenth century, numerous military expeditions towards Gilgit, Astor, and other frontier territories necessitated provision of a continuous line of supply for the troops through forced labor (Knight 1893). Consequently, peasants, boaters, and traders were forced to carry the supplies and baggage of the military (Thorp 1870; Neve 1928). Because they were the politically weaker class (Knight 1893), all these hardships fell unequally onto the Muslim farmers who had to face the brunt of corvee.

\section{Cholera Epidemics}

Cholera struck the Kashmir Valley regularly in several discernible waves since the beginning of the 1800s. An examination of geoecological factors led Lawrence (1895) to determine that villages on the Karewa Plateaus (Pleistocene uplands) seemed free from cholera, in contrast to the alluvial plains, where the disease was most widespread. The alkaline nature of the Karewa soils ( $\mathrm{pH}$ value of about 7.5) constrains the growth and spread of cholera bacteria on the Karewa uplands (Akhtar 2008). Conversely, the center and nursery of cholera in Kashmir was its squalid, lowlying capital, Srinagar, from where the disease spread to towns and villages (Lawrence 1895, p. 219). Unsanitary conditions, unhygienic habits, crowded living conditions, and the intake of tainted water (Elmslie 1875; Climo 1893; Lawrence 1895; Carus-Wilson 1901; Tyndale-Biscoe 1921) had a strong impact on cholera transmission into the human population; rain appears to have increased the spread of the disease into the low-lying areas (Neve 1900). Apart from geoecological factors, the cholera epidemic was brought to Kashmir as a result of human contact, owing to the opening of a road between Baramulla and the Punjab (Lawrence 1895, p. 200).

The outbreak of disease was further intensified by contact between Kashmir and the cholera-prone regions of Jammu during Dogra rule; nearly 10,000 persons were killed in 1880 alone (Mitra 1889). In addition to the endemic nature of cholera epidemics in Kashmir, F.N. Macnamara (1880) provided evidence of its pandemic nature, tracing its movement from Bengal to the northwest provinces via Punjab. Due to Kashmir's connection with Punjab, cholera moved to the valley during the winter months, especially in 1857 (Bates 1873, pp. 110-113). Late in 1888 , the epidemic infected 18,000 people and claimed nearly 10,000 lives in Kashmir; official tallies for 1892 show 16,845 cases and 11,712 deaths; and the year 1900 saw 76,000 infections and 4229 deaths (Neve 1900).

Complementing earlier findings, Clemow (1903) opined that all four global cholera epidemics of the nineteenth century initially erupted in India's lower Ganges Valley. Moreover, recent research confirms the inevitable connection between El Niño and the eruption of infectious cholera (Colwell 2004; Anyamba et al. 2006; McMichael et al. 2006). Historical records reveal that the emergence of cholera during the nineteenth century was concurrent in both time and space with the occurrence of significant El Niño episodes (Davis 2001), including its endemic effects on Kashmir during 1858,1867, 1876, 1880, 1888, and 1892. Under such conditions, the schools and offices in Kashmir were closed and the people preferred to be indoors, waiting to die (Tyndale-Biscoe 1922). They went only to Hakim or placed their trust in the priests' prayers 
and incantations (Tyndale-Biscoe 1922), but they took no precautionary measures.

\section{Hydrometeorological Hazards}

Nineteenth-century Kashmir witnessed extreme hydrometeorological events in the form of intense cold, incessant rains, untimely snowfall, and severe flooding, as well as intermittent experience with droughts in 1834, 1859-1860, 1883, and 1892 . These events represent $35 \%$ of all natural hazard-related disasters over the century. The year 1805 registered extreme cold that resulted in crop failure and ensuing famine. The following decade (1810-1819) was intensely cold, probably the coldest of the past 500 years
(Briffa et al. 1998), synchronous with global cooling effects (Cole-Dai et al. 2009). A search through local flood history reveals many occasions-such as in 1838, 1841, 1893, and 1894-when a rapid rise in water levels, rather than peak discharge, was primarily responsible for flood deaths. In contrast, the incessant rains and severe floods of 1801, 1832, 1865, 1869, 1871, 1878, 1889, and 1900, which posed serious risks to people trapped in their homes and work places and caused damage to property, allowed the population ample response time to move to safer places. Most of these floods were primarily of meteorological origin. The flood of 1885, however, resulted from earthquake-triggered landslides that blocked the river Jhelum at many places along its course, causing damming (Khoihami 1885). The largest flood in terms of peak discharge was the
Fig. 3 Maximum flood inundation area for the 1841 flood depicted on the basis of historical records of the nineteenth century Kashmir

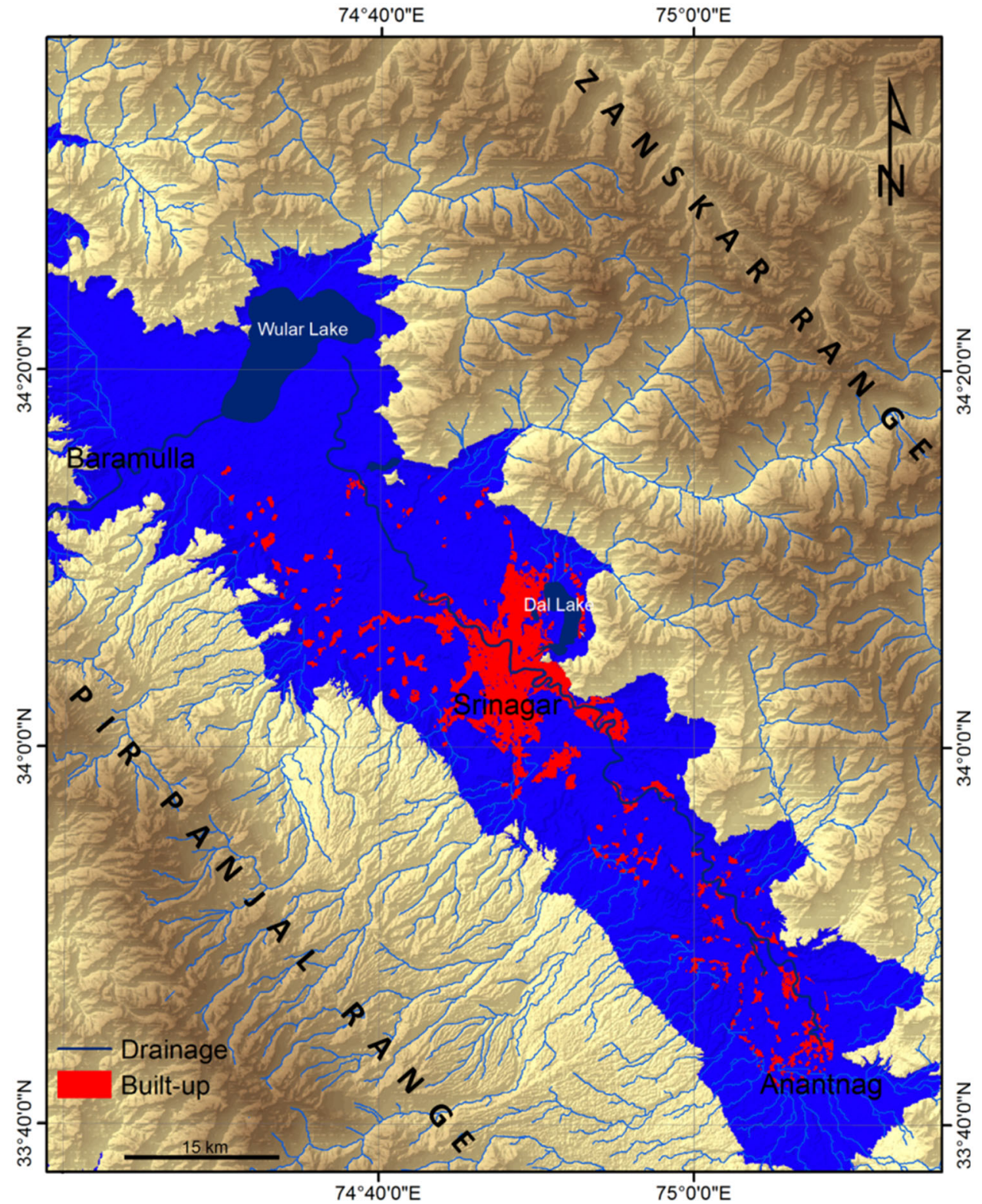


1841 event (Fig. 3), most probably exceeds in damage any other reported event in the last 180 years (Bhat et al. 2019). According to historical sources the flood lasted several weeks and devastated landscapes and ruined farmers.

Calibrating our event-based data against the historical chronology of El Niño Southern Oscillation (ENSO) episodes provided by Quinn et al. (1987), Quinn (1992), Davis (2001), and Gergis and Fowler $(2006,2009)$ indicates that these extreme hydrometeorological events of 1801, 1832, 1838, 1841, 1859-1860, 1865, 1871, 1877-1878, 1892, 1893 , and 1900 were remarkably synchronous with global (very strong) ENSO conditions in the tropical Pacific, which affected the tendency of Asian monsoons toward rain failure and wet extremes (Cook et al. 2010). These ENSO conditions were characterized by rain deficit over the Indian sub-continent, whereas the Kashmir Valley experienced anomalously wet conditions. Contrary to flood events, the drought of 1892 reduced vineyard cultivation by $80 \%$ and equally affected the agrarian population of Kashmir (Ram 1895). Consequently, extreme hydrometeorological events affected the Kashmir population in a pervasive way, exhausting their stores and destroying their assets. Analysis of recently available data suggests that the left bank of the Jhelum was more vulnerable to inundation than the right bank (Ram 1928). It also indicates that the water surface exceeded the maximum elevation levels, overflowing the riverbanks, highlighting the need for protective structures such as dykes and levees along the river channel (Bhat et al. 2019).

Following the flood of 1893, the state started construction of retention walls to prevent flooding (Uppal 1955). In 1901, the government excavated a spill channel, which was designed to take a large portion of flood water from the Jhelum above Srinagar through a swamp before re-joining the river at some distance below the city. This measure has proven to be of much benefit in protecting Srinagar from floods. In 1907, dredging works started from Baramulla up to Wular Lake; these efforts have minimized the chances of floods in the valley and have reclaimed many swamps for agriculture (Dev 1983). However, all these protective measures proved to be insufficient to prevent Kashmir from submergence during the September 2014 Kashmir floods.

\section{Earthquakes}

The nineteenth century witnessed intensive earthquakes that were felt across the Kashmir Valley. Some of these earthquakes, for example, 1824, 1828, 1863, 1878, and 1885 had their epicenters in Kashmir Valley. The seismic episodes of 1803 and 1819 had their epicenters in Garwhal and Allahbund respectively, whereas 1842 and 1892 originated from Afghanistan and were felt strongly as far as in the Kashmir Valley (Ahmad et al. 2015, 2017). Wakefield (1879) refers to the 1824 event as "For in 1824 occurred the terrible earthquakes, followed a few years later by destructive floods, and an epidemic of cholera so severe and so general that it is said that 20,000 people died of it in the capital alone." Similarly, mention of the 1828 earthquake is provided by Vigne (1842, p. 271): “On the night of 26th of June, 1828, at half-past ten, a very severe shock was felt, which shook down a many great houses [...] perhaps 1000 persons were killed, and 1200 houses shaken down; although, being built with a wooden framework, the houses are less liable to fall than an edifice of brick or stone." Kashmir witnessed another seismic event on 1878 that caused extensive damage in the north Kashmir (Khoihami 1885; Koul 1925; Bamzai 1962). A decade later, the most destructive known earthquake of the nineteenth century struck Kashmir Valley in 1885, inflicting severe damage to the natural and built environment (Jones 1885). Notwithstanding the frequency and magnitude of earthquakes in Kashmir, the style of local architecture is unambiguously suited to withstand seismic shocks. Several observers mention the architectural uniqueness of local buildings to resist the seismic vibrations. Moorcroft and Trebeck (1841, p. 279) visited Kashmir in 1823 and documented their observations regarding the general construction of houses: "The peculiarity of their construction was, no doubt, suggested by the occurrence of earthquakes, which are frequent in Kashmir." Similarly, Vigne (1842, p. 283) observes: "houses, of two or three or four stories in height, with gable ends and sloping roofs of wood. The walls are built of brick, burnt or sun-dried, and secured in a frame of wood, as prevention against the effects of an earthquake." Wakefield (1879, p. 95) notes: "The general aspect of the buildings is structures varying in form, height, and material; their bases are a solid stone wall of rough masonry, those with a better built foundation. The walls of the upper structure are usually built of brick, burnt or sundried, and secured in a wooden framework as a precaution against the disintegrating effects of an earthquake" (Fig. 4a, b). Historical discourse reveals that owing to the availability of forest resources, houses were built of timber laid on each other to form a square, and then their openings were filled with bricks and clay in the form of Deji-i-Dewari and Taqq or mixed-mode construction (Fig. 4c, d). Both Deji-i-Dewari and Taqq accounts for the considerable success in reducing seismic risk (Forster 1808; Moorcroft and Trebeck 1841; Vigne 1842; Drew 1875; Wakefield 1879; Lawrence 1895; Neve 1913a). Adaptation through this type of architecture was necessitated by resource availability and local ecological knowledge. Nevertheless, people in Kashmir responded to the recurrent earthquakes through a process of cultural evolution depicted in the 


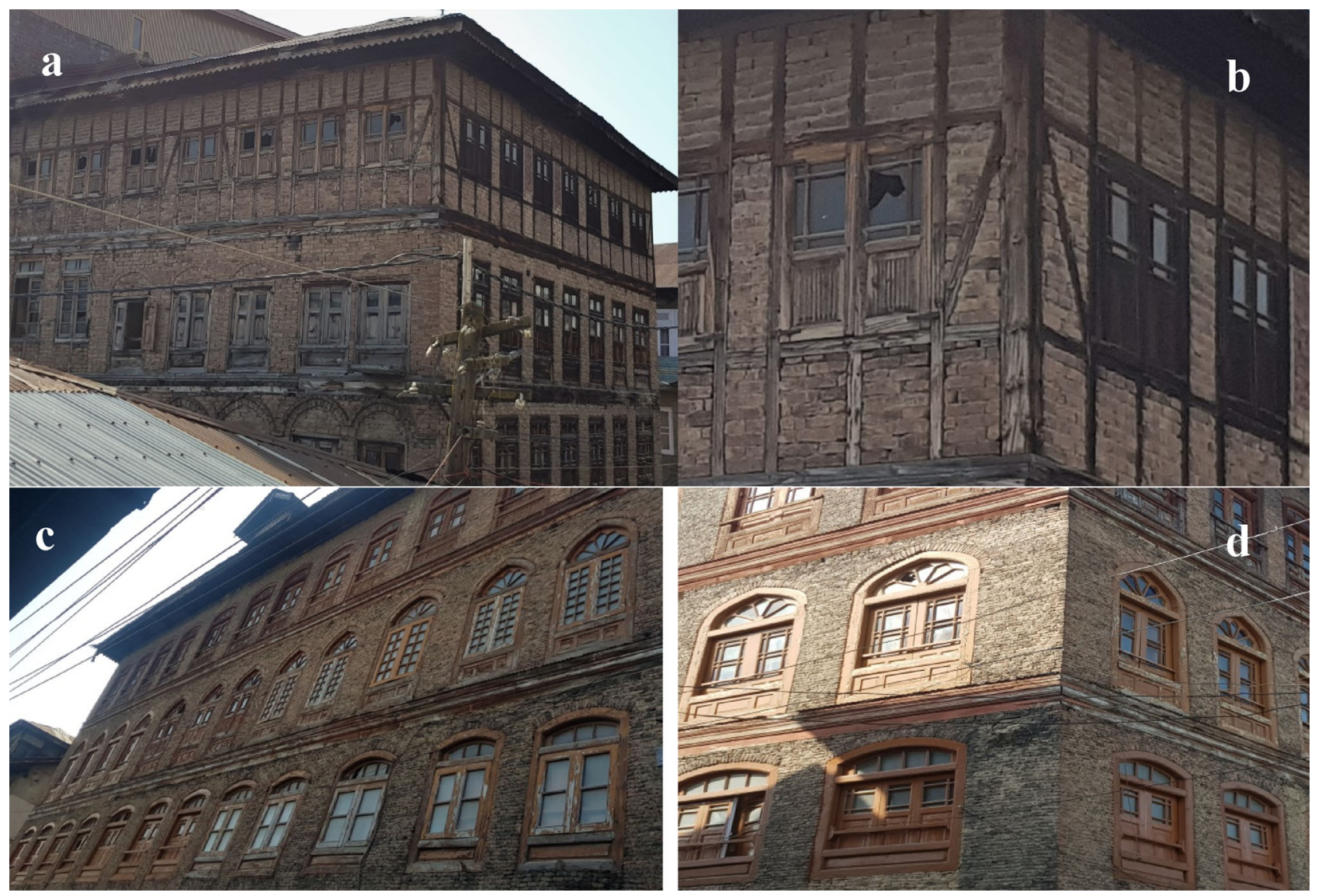

Fig. 4 Deji-i-Dewari construction in which bricks are secured in wooden frame (a, b); and half arch Taqq construction (c, d). Both types of construction show good behavior during seismic shaking. Photographs by Bashir Ahmad on 29 May 2021 in the downtown area of Srinagar.

construction of a vernacular architecture that reduced the impact of seismicity.

\section{Famines}

Seven appalling famines occurred in Kashmir throughout the nineteenth century. These periods of acute food shortage were exacerbated by long-standing local problems that plunged the people into distress with no resources in reserve to enable them to resist famines. For example, famines in 1803, 1805, and 1813 were caused by severe cold spells, which resulted in crops not ripening. Later, in 1819 excessive cold resulted in crop immaturity and massive livestock death, leading to famine so severe that people sold their children (Kachru 1836; Miskeen 1899). Similarly, from 1831 to 1833 extreme climatic conditions prevailed across Kashmir, which began with a sudden and untimely autumn snowfall in 1831 , followed by the severe winter of 1832 when all rivers and lakes were frozen hard, which destroyed paddy crops and resulted in a devastated famine during Sikh rule (Kachru 1836). This situation compelled many people to migrate to different parts
(Amritsar, Delhi, Calcutta, Banaras, and Lahore) of undivided India (Sufi 1948). Finally, after the Dogras overthrew the Sikh regime in 1846, a famine occurred, and later in 1865 due to heavy rains that destroyed the harvest and resulted in scarcity of food, it culminated in a famine (Khoihami 1885).

The great famine of $1877-1878$ was similarly caused by continuous rains (Tyndale-Biscoe 1922) that fell from October 1877 until January 1878, followed by heavy snowfall at a time when rice and maize crops were ripe (Koul 1925). People were demoralized and acted like "ravenous beasts," each struggling for their own life and the helplessness manifested by the non-burial of corpses (Neve 1915, p. 73). Many orphan girls were sold in the city and people were said to have resorted to cannibalism (Koul 1925). There was an enormous loss of life calculated as about 0.25 million people out of the 402,700 population (Khoihami 1885; Wingate 1888; Koul 1925). In June 1879, cholera appeared to aggravate the miseries of the people. Seeing no hope for survival in the valley, thousands of people fled to the adjoining Punjab plains, although their migration was checked by natural (mountainous terrain) and political (colonial restrictions) factors. 
The combined effect of land rights and heavy taxation eroded peasant entitlement and reduced them to the conditions of tenants at will (Wingate 1888), with sporadic climatic shocks that destroyed the crops and made people to suffer from famines (Administrative Report 1877). In view of rigid political economy and colonial restrictions people were forcibly confined within the valley by colonial rulers and made peasants move from one village to another in the hope of finding peace and freedom from oppression (Lawrence 1895). Moreover, rigid political economy prevented people to exploit the natural resources and prevented them to reinvest in pastoral activities (Wingate 1888). Thus, climatic factors, land rights, revenue systems, agricultural practices, diseconomies of scale, and structures of political economy prevented reinvestment in pastoral activities (Lawrence 1895).

\section{Discussion}

Historical discourse on disasters enables us to comprehend the vulnerability and resilience of past societies to repeated natural hazards. The reported human impact from the above disasters during the nineteenth century include death from starvation, disease, migration, abandonment of land, and intended trade of humans or their siblings into bondage, with the most distressing consequence reported among poor population. First, occurrence of famines cannot be explained by climatic causes alone and instead were amplified by land policy, food insecurity and welfare support reminiscent of the medieval conditions of exploitation (Wingate 1888; Lawrence 1895) that resulted in desertion of cultivated land and gradual depopulation of the country. In Kashmir, the land revenue system (ryotwari) reduced the cultivator's capacity to adapt to adverse environmental and economic conditions. This reduced resilience led Lawrence (1895, p. 468) to describe the land system of Kashmir as the "ruined raiyatwari."

Food insecurity had its roots in the rural economy maintained by rigid economic agreements that resulted in agricultural stagnation and widespread poverty, eroded peasant entitlements, and caused food crises and famines. Thus, the nature of disasters was set in society, determined mostly by inherited patterns of exposure that were embedded in social setting and political economy (Watts and Bhole 1993; Wisner et al. 2004; Gaillard and Kelman 2013). Moreover, colonial responses to disasters were disproportionate, privileging influential communities with enhanced safety while subjecting masses to systematic risks and vulnerabilities coupled with the colonial ruler's laissez-faire approach.

In post-colonial Kashmir (after 1947), peasantry with small land holdings have faced food scarcity owing to fluctuations in annual production when disasters strike (Mander and Saxena 2009). These food crises, touching over $60 \%$ of the present population of Kashmir, have resulted in malnutrition and chronic poverty, which pose serious hunger problems (Hussain 2007), despite India's fiscal progress in recent years (Global Hunger Index 2019; UNICEF 2019). Moreover, a food entitlement of $5 \mathrm{~kg}$ of foodstuff per person is too minimal to sustain an adult life for a month within the Force Majeure provision in the National Food Security Act (NFSA) that prohibits governments from providing food at all times including in the event of disaster (Akerkar 2015), thus constraining the rights of people during a disaster. In the case of epidemics, absent basic sanitary facilities and a primary healthcare system, people choose to quarantine themselves or decided to die in the event of cholera epidemics (Tyndale-Biscoe 1922).

For hydrometeorological hazards, especially floods, people relocated their settlements from floodplains to higher elevations and saved whatever they could. However, inclement weather disturbances over Kashmir often lead to frequent road closures during the wet seasons (snowfall, avalanches, and landslides) and, also during the similar environmental events (such as earthquakes and floods), affect the entire supply chain, thereby pushing large populations into hunger and starvation (Mander and Saxena 2009). Lastly, in view of intense events like earthquakes, people in Kashmir during the nineteenth century explicitly adapted wooden-frame architecture as a coping strategy.

\section{Conclusion}

Disasters in Kashmir in the nineteenth century demonstrate intersecting events and processes in which disaster-affected people in Kashmir were marginalized geographically because they lived in hazardous places; socially because they were members of lower classes; economically because they were underprivileged; and politically because their collective voice was unheeded. The findings from this study provide event and impact scenarios with known risks, complemented by probabilistic risk management strategies as a foundation for resilience against disasters. Realistic disaster scenarios transform experience and memory into local knowledge that can be used as a template to reduce risk today, as it did during the nineteenth century. These strategies call for reforming public safety policies and developing robust disaster risk responses at the local and national levels. As a corollary, historical disaster research is a valuable approach by which to determine periods in history with analogous disaster trajectories. These comparative insights are much needed to reduce risk that arises 
out of such processes, since such pre-disaster patterns of vulnerabilities may be found locally or globally.

Acknowledgements The authors are thankful to Mahmood Ahmad Shah (Director, Handicrafts Kashmir) for providing us library facilities. Thanks are due to all personnel at the Women's College library, Srinagar, especially Farhat Jahan (chief librarian), and Ms. Yasmeen Wani (chief librarian) of Degree College Pulwama, for help in collating the details of historical disasters. Thanks are also due to Prof. Mushtaq Ahmad of the Institute of Management, Public Administration \& Rural Development (IMPA), Srinagar for providing us library facilities.

Open Access This article is licensed under a Creative Commons Attribution 4.0 International License, which permits use, sharing, adaptation, distribution and reproduction in any medium or format, as long as you give appropriate credit to the original author(s) and the source, provide a link to the Creative Commons licence, and indicate if changes were made. The images or other third party material in this article are included in the article's Creative Commons licence, unless indicated otherwise in a credit line to the material. If material is not included in the article's Creative Commons licence and your intended use is not permitted by statutory regulation or exceeds the permitted use, you will need to obtain permission directly from the copyright holder. To view a copy of this licence, visit http://creativecommons. org/licenses/by/4.0/.

\section{References}

Administrative Report of the Punjab and its Dependencies for 1875-1876. 1877. Printed at the Punjab Government Civil Secretariat Press. Lahore, Pakistan.

Administrative Report of the Punjab and its Dependencies for 1878-1879. 1880. Printed at the Punjab Government Civil Secretariat Press. Lahore, Pakistan.

Administrative Report of the Punjab and its Dependencies for 1894-1895. 1896. Printed at the Punjab Government Civil Secretariat Press. Lahore, Pakistan.

Ahmad, B., S. Ahmad, A. Alam, S. Wang, and M.S. Bhat. 2015. Looking for missing links in Kashmir: An update on nineteenth century seismicity. Seismological Research Letters 86(4): 1219-1224.

Ahmad, B., A. Alam, M.S. Bhat, S. Ahmad, M. Shafi, and R. Rasool. 2017. Seismic risk reduction through indigenous architecture in Kashmir Valley. International Journal of Disaster Risk Reduction 21: 110-117.

Ahmad, B., H. Sana, and A. Alam. 2014. Macroseismic intensity assessment of 1885 Baramulla earthquake of northwestern Kashmir Himalaya, using the environmental seismic intensity scale (ESI 2007). Quaternary International 321: 59-64.

Akerkar, S. 2015. Development of a normative framework for disaster relief: Learning from colonial famine histories in India. Disasters 39(S2): S219-S243.

Akhtar, R. 2008. Environment and cholera in Kashmir during nineteenth-century. Indian Journal of History of Science 43(2): 211-230.

Anyamba, A., J.P. Chretien, J. Small, C.J. Tucker, and K.J. Linthicum. 2006. Developing global climate anomalies suggest potential disease risks for 2006-2007. International Journal of Health Geographics 5(60): 1-8.

Bamzai, P.N.K. 1962. Socio-economic history of Kashmir: 18461925. New Delhi, India: Metropolitan Book Co.
Bankoff, G. 2007. Comparing vulnerabilities: Toward charting an historical trajectory of disasters. Historical Social Research 32(3): 103-114.

Bates, C.E. 1873. A gazetteer of Kashmir. New Delhi, India: Light \& Life Publishers.

Bazaz, P.N. 1941. Kashmir in crucible. Srinagar, Kashmir: Pamposh Publications.

Bellew, H.W. 1875. Kashmir and Kashghar: A narrative of the journey of the embassy to Kashghar in 1873-74. London: Trubner \& Co. (Palala Press 2015).

Bhat, M.S., B. Ahmad, A. Alam, and A.F. Hakim. 2019. Flood hazard assessment of Kashmir Valley using historical hydrology. Journal of Flood Risk Management 12(51): Article e12521.

Briffa, K.R., P.D. Jones, F.H. Schweingruber, and T.J. Osborn. 1998. Influence of volcanic eruptions on northern hemisphere summer temperature over the past 600 years. Nature 393(6684): $450-455$.

Burton, I. 2010. Forensic disaster investigation in depth: A new case study model. Environment 52(5): 36-41.

Carus-Wilson, A. 1901. A woman's life for Kashmir: Irene Petrie, a biography. New York: Fleming H. Revell.

Clemow, F.G. 1903. The geography of disease. New York: Cambridge University Press.

Climo, W.H. 1893. The floods in Kashmir and Srinagar: A new focus of endemic cholera. British Medical Journal 2(1702): 396-397.

Cole-Dai, J., D.G. Ferris, A.L. Lanciki, J. Savarino, M. Baroni, and M.H. Thiemens. 2009. Cold decade (AD 1810-1819) caused by Tambora (1815) and another (1809) stratospheric volcanic eruption. Geophysical Research Letters 36(22): Article L22703.

Collette, J. 1884. A guide for visitors to Kashmir. Revised by A. Mitra, 1898. Calcutta, India: W. Newman \& Co.

Colwell, R.R. 2004. Infectious disease and environment: Cholera as a paradigm for waterborne disease. International Microbiology 7(4): 285-289.

Cook, E.R., K.J. Anchukaitis, B.M. Buckley, R.D. D'Arrigo, W.E. Wright, and G.C. Jacoby. 2010. Asian monsoon failure and mega drought during the last millennium. Science 328(5977): 486-489.

Davis, M. 2001. Late Victorian Holocausts: El Niño famines and the making of the third world. London: Verso.

Dedamari, K.M.A. 1747. Waqat-i-Kashmir. Persian manuscript Folios 296. Srinagar, India: Research \& Publication Division, Library Srinagar, University of Kashmir.

Dev, J.S. 1983. Natural calamities in Jammu and Kashmir. New Delhi, India: Ariana.

Diamond, J., and J.A. Robinson. 2010. Natural experiments of history. Cambridge: Harvard University Press.

Digby, W. 1890. Condemned unheard: The Government of India and H.H. the Maharaja of Kashmir: A Letter to the Rt. Hon. Sir Ughtred Kay-Shuttleworth. London: Indian Political Agency.

Drew, F. 1875. The Jummoo and Kashmir territories: A geographical account. London: Edward Stanford.

Elmslie, W.J. 1875. Seed time in Kashmir: A memoir of William Jackson Elmslie. London: James Nisbet.

Forster, G. 1808. A journey from Bengal to England, through the northern part of India, Kashmire, Afghanistan, and Persia, and into Russia by the Caspian Sea. London: Faulder \& Sons.

Gaillard, J.C., and I. Kelman. 2013. Disaster research and policy, history. In Encyclopaedia of natural hazards, ed. P.T. Bobrowsky, 160-164. Heidelberg, Germany: Springer.

Gergis, J.L., and A.M. Fowler. 2006. How unusual was late $20^{\text {th }}$ century El Niño-Southern Oscillation (ENSO)? Assessing evidence from tree-ring, coral, ice-core and documentary palaeoarchives, A.D. 1525-2002. Advances in Geosciences 6: 173-179. 
Gergis, J.L., and A.M. Fowler. 2009. History of ENSO events since A.D. 1525: Implications for future climate change. Climatic Change 92(3): 343-387.

Global Hunger Index. 2019. Dublin, Ireland: Concern Worldwide and Welthungerhilfe (WHH).

Gracia-Acosta, V. 2002. Historical disaster research. In Catastrophe and culture: The anthropology of disaster, ed. S.M. Hoffman, and A. Oliver-Smith, 49-66. Santa Fe, New Mexico: School of American Research Press.

Grayson, D.K., and P.D. Sheets. 1979. Volcanic disasters and the archaeological record. In Volcanic activity and human ecology, ed. P.D. Sheets, and D.K. Grayson, 623-632. London: Academic Press.

Hassan, M. 1959. Kashmir under the Sultans. Srinagar, Kashmir: Ali Mohammad \& Sons.

Hügel, B.C. 1836. Notice of a visit to the Himmáleh Mountains and the Valley of Kashmir, in 1835. Journal of the Royal Geographical Society 6: 343-349.

von Hügel, C.A. 1845. Travels in Kashmir and the Panjab. London: John Petheram.

Hussain, T.A. 2007. On the brink: A report on the climate change and its impact in Kashmir. Srinagar, India: Books for Change.

Ince, J. 1888. Ince's Kashmir handbook: A guide for visitors, rewritten and much enlarged by Joshua Duke. Calcutta, India: Thacker, Spink and Co.

India. Quarter Master General's Department. Intelligence Branch. 1890. Gazetteer of Kashmir \& Ladak. Calcutta: Superintendent of Government Printing.

IRDR (Integrated Research on Disaster Risk). 2015. The FORIN project: Understanding the causes of disasters. Beijing, China: Integrated Research on Disaster Risk.

Jahn, T., and P. Wehling. 1998. Social nature conditions: Contours of a theoretical concept (Gesellschaftliche Naturverhältnisse: Konturen eines theoretischen Konzepts). In Sociology and nature: Theoretical perspectives (Soziologie and Natur: Theoretische Perspektiven), ed. K.-W. Brand, 75-93. Wiesbaden, Germany: VS Verlag für Sozialwissenschaften (Springer) (in German).

Jammu and Kashmir Political. 1889. No. 39.

Jones, E.J. 1885. Notes on the Kashmir Earthquake of $30^{\text {th }}$ May 1885. Records of the Geological Survey of India 18(3): 153-156.

Kachru, P.B. 1836. Majmu'-ut-Tawarikh. Persian manuscript. Srinagar, India: Research \& Publication Division, Srinagar Library, University of Kashmir.

Kelman, I., J. Field, S. Kavita, and G.M. Bhat. 2018. Disaster diplomacy in Jammu and Kashmir. International Journal of Disaster Risk Reduction 31: 1132-1140.

Khanyari, G.N. 1893. Wajeez-ul-Tawarikh. Persian manuscript. Srinagar, India: Research \& Publication Division, Srinagar Library, University of Kashmir.

Khasta, P.H.G. 1888. Guldast-i-Kashmir. New Delhi, India: Kitab Ghar, Billimaran.

Khoihami, P.G.H. 1885. Tarikh-i-Hassan. Persian manuscript. Vols. I-II, folios 511 and 263. Srinagar, India: Research \& Publication Division, Srinagar Library, University of Kashmir.

Knight, E.F. 1893. Where three empires meet: A narrative of recent travel in Kashmir, western Tibet, Gilgit and the adjoining countries. London: Longmans.

Koul, A.N. 1710. The Muntakhab-u-Tawarikh. Srinagar, India: Research \& Publication Division, Srinagar Library, University of Kashmir.

Koul, P.A. 1925. Geography of Jammu \& Kashmir State. Calcutta, India: Thacker, Spink and Co.

Lawrence, W.R. 1895. The Valley of Kashmir. Oxford: Henry Frowde, Oxford University Press.
Leroy, S.A.G. 2011. Historical events. In Encyclopaedia of natural hazards, ed. P.T. Bobrowsky, 452-470. Heidelberg, Germany: Springer.

Macnamara, F.N. 1880. Climate and medical topography in their relation to the disease distribution of the Himalayan and subHimalayan districts of British India, with reasons for assigning a malarious origin to goitre and some other disease. London: Longmans, Green \& Co.

Mander, H., and N.C. Saxena. 2009. Hunger in the valley: Report on the implementation of food and livelihood schemes of Government in Kashmir. Department of Social Work: University of Kashmir.

McMichael, A.J., R.E. Woodruff, and S. Hales. 2006. Climate change and human health: Present and future risks. Lancet 367(9513): 859-869.

Miskeen, Mohi-ud-din. 1899. Tarikh-i-Kabir Kashmir. Research \& Publication Division, Srinagar Library. Persian manuscript. Vols. I-II, folios 370 and 28.

Mitra, A. 1889. Medical and surgical practices in Kashmir. Lahore, Pakistan.

Moorcroft, W., and G. Trebeck. 1841. Travels in the Himalayan Provinces of Hindustan and the Panjab; in Ladakh and Kashmir; in Peshawar, Kabul, Kunduz, and Bokhara; from 1819-1825. London: John Murray.

Neve, A. 1885. The late earthquake in Kashmir. Lancet 126(3236): Article 455.

Neve, A. 1913a. Thirty years in Kashmir. London: Edward Arnold.

Neve, A. 1913b. Tourist guide to Kashmir, Ladakh, Iskhardo. Lahore, Pakistan: Civil and Military Gazette Press.

Neve, E.F. 1900. A brief account of the recent epidemic of cholera in Kashmir. British Medical Journal 2(2085): 1705-1706.

Neve, E.F. 1915. Beyond the Pir Panjal: Life among the mountains and valleys of Kashmir. Salisbury Square, London: Church Missionary Society.

Neve, E.F. 1928. A crusader in Kashmir. London: Seeley, Service and Co.

Oliver-Smith, A. 1999. What is a disaster? Anthropological perspectives on a persistent question. In The angry earth: Disaster in anthropological perspective, ed. A. Oliver-Smith, and S.M. Hoffman, 18-34. London: Routledge.

Oliver-Smith, A., and S.M. Hoffman. 2002. Why anthropologists should study disasters. In Catastrophe \& culture: The anthropology of disaster, ed. S.M. Hoffman, and A. Oliver-Smith, 3-22. Santa Fe, New Mexico: School of American Research Press.

Palerm, A. 1980. Anthropologíay Marxismo. Mexico, D.F.: Centro de Investigaciones superiores del instituto Nacional de Antropología e Historia / Editorial Nueva Imagen (in Spanish).

Paremu, R.K. 1977. A history of Sikh Rule in Kashmir. Srinagar, India: Government Press.

Purdon, W.H. 1861. On the trigonometrical survey and physical configuration of the Valley of Kashmir. Journal of the Royal Geographical Society 31: 14-30.

Quinn, W.H. 1992. A study of Southern Oscillation-related climatic activity for A.D. 622-1900 incorporating Nile River flood data. In El Nino historical and paleoclimatic aspects of the Southern Oscillation, ed. H.F. Diaz, and V. Markgraf, 119-149. New York: Cambridge University Press.

Quinn, W.H., V.T. Neal, and S.E. Antunez De Maylo. 1987. El Nino occurrences over the past four and a half centuries. Journal of Geophysical Research 92(C13): 14449-14461.

Rai, M. 2004. Hindu rulers, muslim subjects: Islam, rights, and the history of Kashmir. Princeton, NJ: Princeton University Press.

Ram, B. 1891. Census of India: Reports on the Jammu and Kashmir State. Lahore, Pakistan: W. Ball and Co. 
Ram, G. 1928. Floods in Jammu and Kashmir. Jammu and Kashmir government flood management report. Published by the State Government.

Ram, P.B. 1895. Report on the administration of the Jammu and Kashmir State for 1892-93. Jammu, India: Rambir Prakash Press.

Riede, F. 2014. Towards a science of past disasters. Natural Hazards 71: 335-362.

Riede, F. 2017. Past-forwarding ancient calamities: Pathways for making archaeology relevant in disaster risk reduction research. Humanities 6(4): Article 79.

Schenk, G.J. 2014. Common grounds in early modern disaster experiences? Some remarks on new trends in historical disaster research as part of environmental history and climate history. In An environmental history of the early modern period: Experience and perspective, ed. M. Knoll, and R. Reith, 11-18. Zurich: LIT Verlag.

Schonberg, B.E.V. 1853. Travels in India and Kashmir, vol 1. London: Huest and Blackett.

Shoemaker, M.M. 1912. Indian pages and pictures: Rajputana, Sikkim, the Punjab, and Kashmir. New York: G.P. Putman Sons.

Sufi, G.M.D. 1948. Kashir. Lahore University of Punjab. Vol. II. New Delhi, India: Capital Publishing House.

Suri, S. 1849. Umdat-ut-Tawarikh. Persian manuscript. Srinagar, India: Research \& Publication Division, Srinagar Library.
Thorp, R. 1870. Cashmere misgovernment. London: Longmans, Green, and Co.

Tyndale-Biscoe, C.E. 1921. Thomas Russell Wade: A pioneer in Kashmir. London: Church Missionary Society.

Tyndale-Biscoe, C.E. 1922. Kashmir in sunlight and shade. London: Seeley, Service and Co.

Uppal, H.L. 1955. Book on River Jhelum, data collection section. Srinagar, India: P\&P, Floods Division.

UNICEF (United Nations International Children's Emergency Fund). 2019. UNICEF annual report. New York: UNICEF Division of Commission.

Vigne, G.T. 1842. Travels in Kashmir, Ladak, Iskardo, the countries adjoining the mountain-course of the Indus, and the Himalaya, north of the Panjab, 2nd edn. London: H. Colburn.

Wakefield, W. 1879. The Happy Valley: Sketches of Kashmir and the Kashmiris. London: S. Low, Marston, Searle, \& Rivington.

Watts, M.J., and H.G. Bhole. 1993. The space of vulnerability: The causal structure of hunger and famine. Progress in Human Geography 17(1): 69-76.

Wingate, A. 1888. Preliminary report of settlement operations in Kashmir and Jammu. Lahore, Pakistan: W. Ball and Co.

Wisner, B., P.P. Blaikie, T. Cannon, and I. Davis. 2004. At risk: Natural hazards, people's vulnerability and disasters, 2nd edn. London: Routledge. 